\title{
Lysosomal enzymes and vitamin E deficiency
}

\section{Gestation-resorption in the rat}

\author{
By J. BUNYAN, J. GREEN AND A. T. DIPLOCK \\ Walton Oaks Experimental Station, Vitamins Ltd, Tadworth, Surrey \\ AND D. ROBINSON \\ Department of Nutrition, Queen Elizabeth College, London, $W 8$
}

(Received 6 June i966-Accepted 19 September 1966)

\begin{abstract}
I. Activities of $\beta$-glucuronidase, $\beta$-galactosidase, acid phosphatase and cathepsin were measured in the uterine contents of normal rats during gestation and of vitamin E-deficient rats during foetal resorption.

2. $\beta$-Glucuronidase activity reached a peak value on days II and 12 , falling to lower values by day 14 . Deficient rats showed slightly greater mean values than normal rats on days I I and I2, but not after that time.

3. Vitamin $\mathrm{E}$ deficiency did not affect the activities of $\beta$-galactosidase, acid phosphatase and cathepsin, all of which showed a slow decrease during pregnancy.

4. The supernatant fraction of homogenates of uterine contents from deficient rats showed increased $\beta$-glucuronidase and $\beta$-galactosidase activity from day $I_{4}$ to 17 , suggesting some degree of rupture of the lysosomal membrane.

5. $\beta$-Glucuronidase and acid phosphatase activities were raised in the uteruses of some deficient rats towards the end of pregnancy, but $\operatorname{serum} \beta$-glucuronidase was unaffected.

6. Changes in lysosomal hydrolases were not so marked during gestation-resorption as in some other vitamin E deficiency states, such as muscular dystrophy in the chick and rabbit.
\end{abstract}

Failure of reproduction in the rat was the first recognized sign of vitamin $\mathrm{E}$ deficiency (Evans \& Bishop, I922). Later, Evans \& Burr (1927) examined in detail the histological changes occurring in the embryos of vitamin E-deficient rats. Since that time, gestation-resorption has become established as the basis for the standard biological assay for vitamin $\mathrm{E}$ (Mason \& Harris, 1947).

The initiation of tissue degeneration in various other vitamin $\mathrm{E}$ deficiency states has lately been attributed to free-radical damage of sensitive cell structures proceeding unchecked in the absence of the vitamin. In vitamin E-deficient chicks and rabbits, rupture of the lysosomal membranes of dystrophic muscle liberates hydrolases from. the unbound state and the total enzyme activity is raised by invading macrophages and phagocytic leucocytes (Desai, Calvert, Scott \& Tappel, 1964; Zalkin, Tappel, Caldwell, Shibko, Desai \& Holliday, r962). However, Desai, Calvert \& Scott (1964) reached somewhat different conclusions in later tests on muscular dystrophy in chicks. When muscle degeneration was reversed by dietary methionine, there was no parallel decrease in 'tissue peroxidizability' and, furthermore, their studies on $\beta$-glucuronidase did not suggest a direct role for lysosomal enzymes in the causation of the disease.

It seemed important to us to investigate the embryos of vitamin E-deficient rats to see whether hydrolytic enzymes were involved in the initiation of embryonic death and in the subsequent dispersal of degenerating tissue. Some interesting changes in 
the $\beta$-glucuronidase activity of normal rat placentae were discovered by Bulmer (1962) using histochemical techniques. The $\beta$-glucuronidase activity of the visceral yolk sac became intense between days 9 and I I and remained so until nearly full term. This sudden rise just precedes day I3, when, according to Evans \& Burr (r927), the vitamin E-deficient embryo dies. For this reason we paid considerable attention to $\beta$-glucuronidase in our tests as well as investigating $\beta$-galactosidase, acid phosphatase and cathepsin.

\section{EXPERIMENTAL}

Dietary ingredients and enzyme substrates. These have been described by Bunyan, Green, Diplock \& Robinson (1967).

Diets. The vitamin E-deficient diet, $\alpha_{3}$, had the percentage composition: $\alpha$-protein 20, DL-methionine 0.56 , lard 3 , salt mixture 3 , vitamin mixture 0.4 , sugar $3^{6}$ and glucose 37. The salt mixture supplied (g/kg diet) $\mathrm{CaCO}_{3} 8 \cdot 37, \mathrm{CaH}_{4}\left(\mathrm{PO}_{4}\right)_{2} \cdot{ }_{2} \mathrm{H}_{2} \mathrm{O}$ I5.32, $\mathrm{Na}_{2} \mathrm{CO}_{3} 0.85, \mathrm{KCl} 2 \cdot 77, \mathrm{MgSO}_{4} . \mathrm{H}_{2} \mathrm{O} 2 \cdot 27$, ferric citrate $0.15, \mathrm{MnSO}_{4} \cdot{ }_{4} \mathrm{H}_{2} \mathrm{O}$ $0.20, \mathrm{ZnSO}_{4} .7 \mathrm{H}_{2} \mathrm{O} 0.06 \mathrm{r}, \mathrm{KI} 0.0003$, NaF 0.00025, $\left(\mathrm{NH}_{4}\right)_{6} \mathrm{Mo}_{7} \mathrm{O}_{24} \cdot 4 \mathrm{H}_{2} \mathrm{O} 0.0002$, $\mathrm{CoSO}_{4} \cdot{ }_{7} \mathrm{H}_{2} \mathrm{O} 0.010, \mathrm{Na}_{2} \mathrm{SeO}_{3} 0.000 \mathrm{I}, \mathrm{CuSO}_{4} \cdot{ }_{5} \mathrm{H}_{2} \mathrm{O}$ 0.014. The vitamin mixture supplied $(\mathrm{mg} / \mathrm{kg})$ : thiamine 9 , riboflavine 19 , nicotinic acid 9o, pyridoxine 9 , calcium pantothenate $9 \circ$, folic acid 2 , cyanocobalamin $0 \cdot 3$, inositol $90, p$-aminobenzoic acid $9 \circ$, choline dihydrogen tartrate 900 , menapthone sodium bisulphite 0.28 and, in the form of gelatin-coated beadlets, vitamin $\mathrm{A}$ I I i.u./g and vitamin $\mathrm{D}_{3} \mathrm{I} \cdot 5 \mathrm{i.u} . \mathrm{g}$.

Rats. Female Norwegian hooded rats were given the vitamin E-deficient diet from I4 days old. At 9 months old most of them were mated with stock colony males to prove their sterility, and then, at 13 months old, they were mated again for the enzyme studies. The time of mating (called day $\mathrm{O}$ ) was established by the appearance of a vaginal plug or by finding spermatozoa in daily vaginal smears. Tissues were taken from ninety-five rats at various stages of pregnancy after day 7 . Forty-three of these rats were given $\mathrm{r}$ or $2 \mathrm{mg} \mathrm{D}$ - $\alpha$-tocopheryl acetate on days 7 and 8 in order to produce a live litter; some tests were also done with four rats given either the deficient diet supplemented with vitamin E, Ioo ppm, or the stock colony diet. Fifteen of the fiftytwo undosed rats had not been proven sterile in a previous mating and were dissected too early in pregnancy for the degeneration of the foetus to be seen clearly. That they were sterile, however, can be deduced from the $100 \%$ incidence of sterility in the other undosed rats. For the sake of brevity, rats given vitamin $\mathrm{E}$ will be referred to as 'normal' rats and those not given vitamin $\mathrm{E}$ as 'deficient' rats.

Preparation of homogenates. Rats were killed by breaking their necks. Their uteruses were removed rapidly and weighed and the number of embryos was counted. The embryos and placentas were dissected and blotted to remove excess moisture, including amniotic fluid, and weighed. Homogenates and subcellular fractions were prepared as described by Bunyan et al. (1967). Uteruses were treated in the MSE homogenizer as described for breast muscle. Foetuses and placentas were homogenized as described for other soft tissues, well-formed foetuses in the later stages of development being first chopped with scissors.

Enzyme assays. $\beta$-Glucuronidase (EC 3.2.1.31.), $\beta$-galactosidase (EC 3.2.1.23), 
cathepsin and acid phosphatase ( $\beta$-glycerophosphatase EC 3.1.3.2.) were assayed as described by Bunyan et al. ( 1967 ). Because Triton X-10o caused turbidity in the phosphate assay, total acid phosphatase activity was liberated from homogenates in sucrose solution by diluting them threefold in water, blending for 3 min in the MSE homogenizer at about $1000 \mathrm{rev} / \mathrm{min}$ and then freezing and thawing them rapidly, three times.

Protein determination. The Kjeldhal method was used.

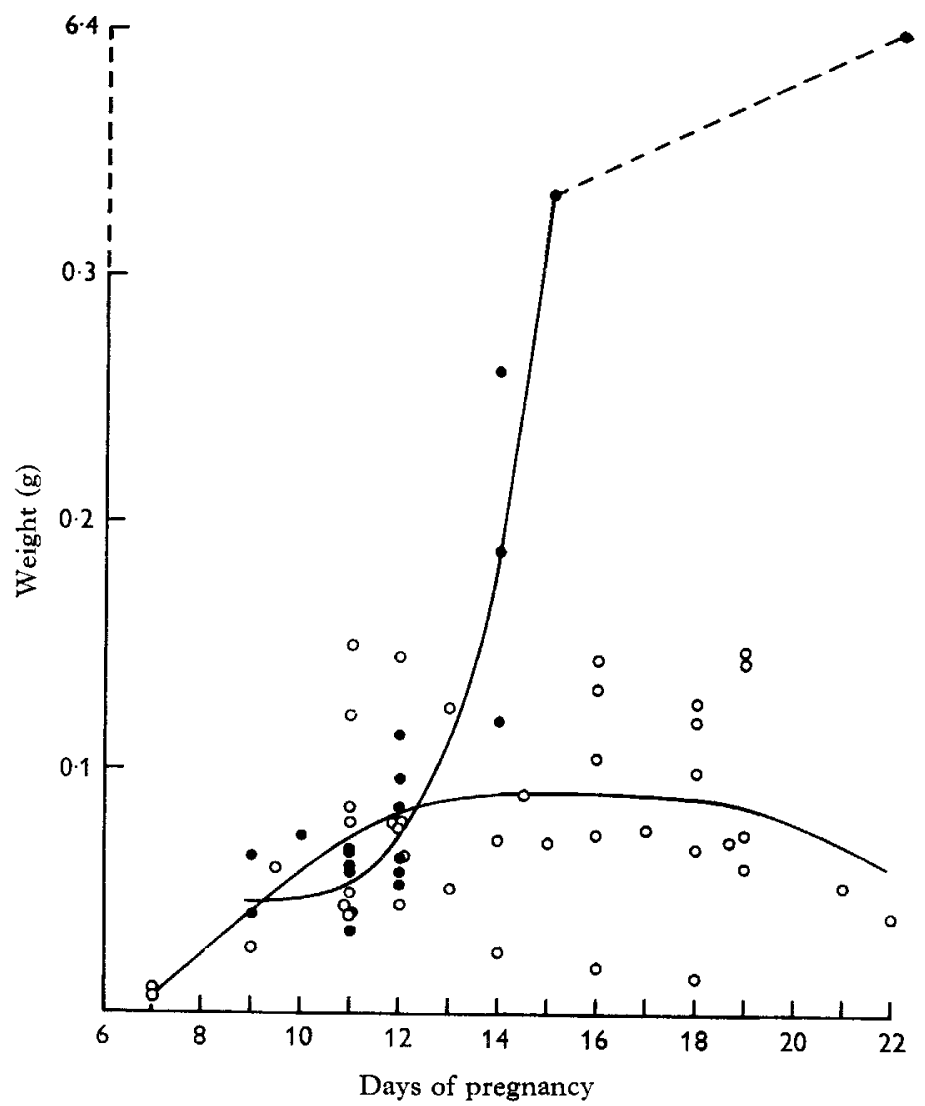

Fig. I. Changes in weight of foetus and placenta during pregnancy. $\circ$, deficient rats;

-, normal rats (see p. r 38 ).

RESULTS

\section{Embryo and placenta}

Weight and protein content (Figs. I, 2). Fig. I shows the changes in weight of tissue per implantation site during the course of normal pregnancy and in resorption of the litter in deficient rats. There was little difference between the two until about day I2, when the deficient embryos declined in weight, the normal ones increasing greatly. At about 12 days the normal foetus is very small in weight compared to the placenta, but between 16 and 22 days it increases, from about $60 \%$ of their combined weight, to about $90 \%$. Evans \& Burr (1927) found that the volume of the I I-day embryo was 
only $40 \%$ of the volume of the placenta. There were some important changes in the protein content of homogenates of embryo plus placenta in the second half of pregnancy (Fig. 2). Uterine contents from normal and deficient rats contained about 95-100 $\mathrm{mg}$ protein/g on day I $\mathrm{I}$, but after this time they diverged greatly; normal values decreased to about $60 \mathrm{mg} / \mathrm{g}$, while results for deficient rats reached a maximum of $195 \mathrm{mg} / \mathrm{g}$ on days 18 and $\mathrm{I} 9$ and then decreased again. This striking difference in protein content can be attributed to dehydration of the resorbing foetus; the drymatter content of the uterine-deficient rats was found to be $25 \%$ (250 mg protein $/ \mathrm{g}$ ) on day 19 compared to $13 \%$ in the normal rat (90 $\mathrm{mg}$ protein $/ \mathrm{g}$ ).

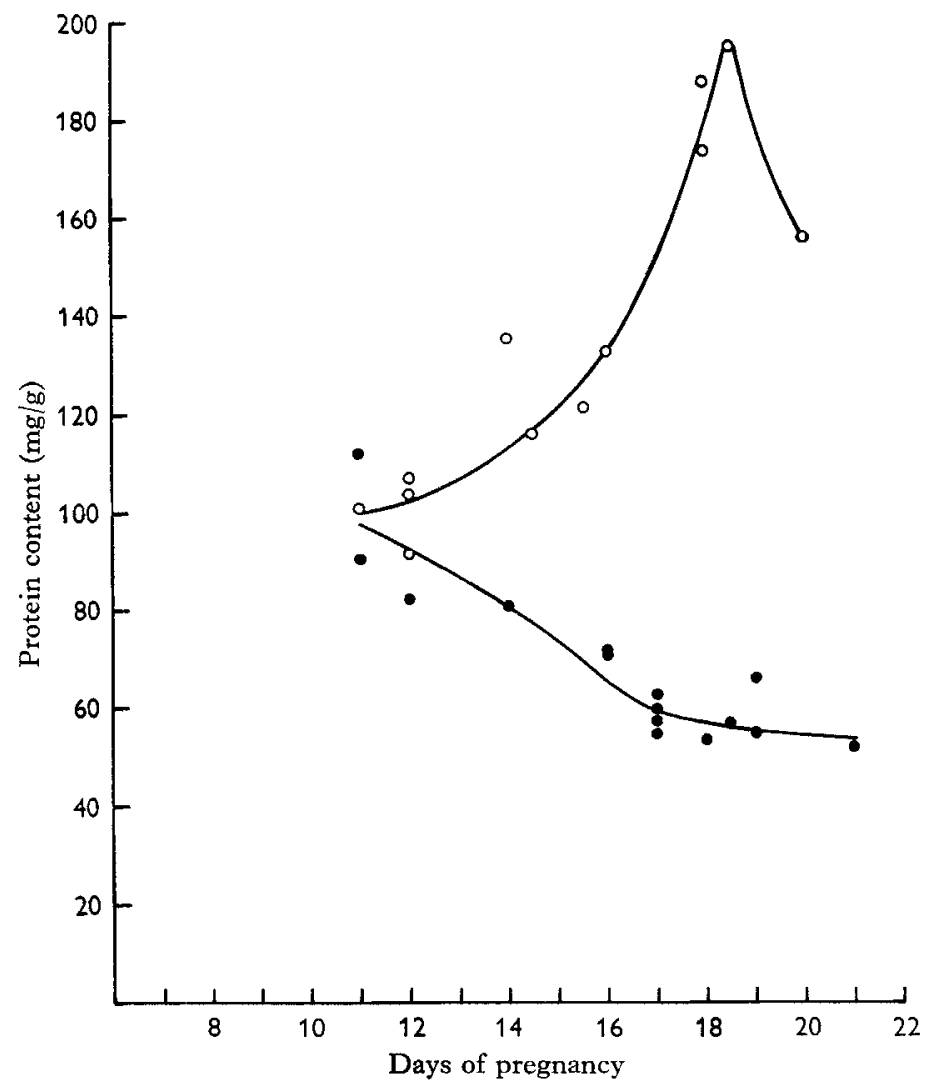

Fig. 2. Changes in protein content of foetus and placenta during pregnancy. $\circ$, deficient rats; $\bullet$, normal rats (see p. 138 ).

$\beta$-Glucuronidase activity (Figs. 3 and 4 ). In both normal and deficient rats $\beta$-glucuronidase activity increased after day 7 , reaching a maximum value on days i I and 12 (Fig. 3). Thereafter, activities decreased rapidly, reaching half the peak value by day I4 and then declining still further. The greater variability of the results for deficient rats on days II and I2 may have been due to differing rates of degeneration of the foetus, coupled with the rapidly changing enzyme activity at this time; Evans \& Burr (1927) found that the time of death varied even for neighbouring sites in the same gestation. 
Although there was no significant difference between the mean peak values, it may be worth noting that the highest values recorded were for deficient rats. When results were expressed as units/implantation site, $\beta$-glucuronidase activity still showed a maximum on days II and I2, but thereafter the shape of the graph was influenced

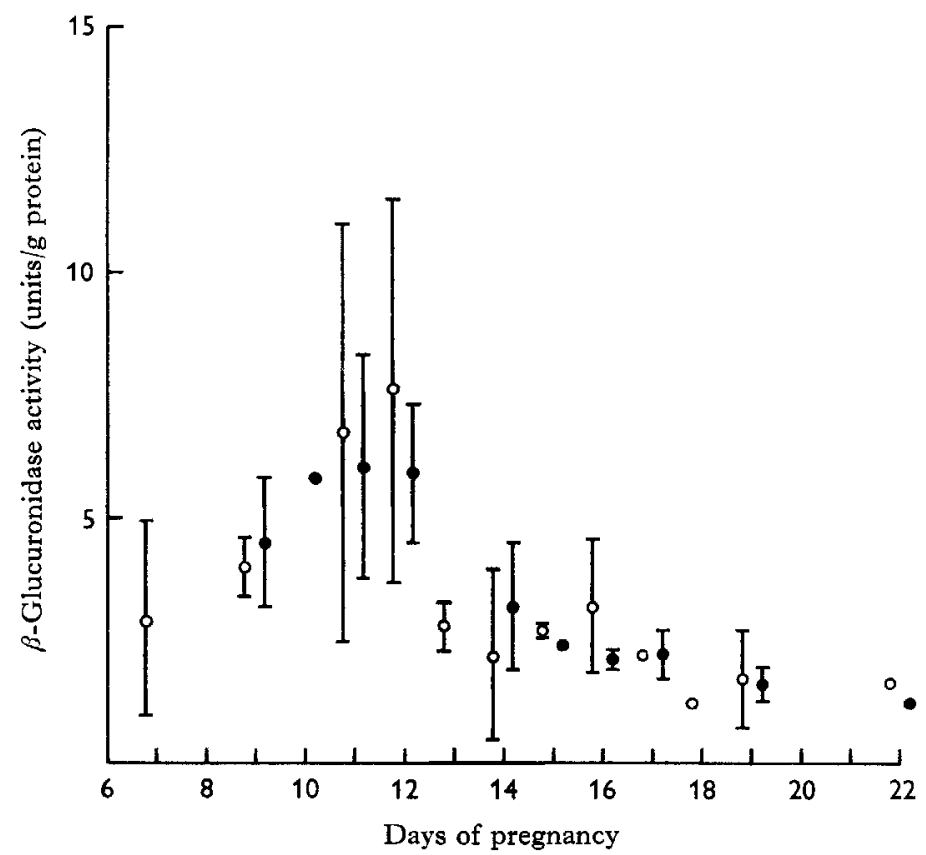

Fig. 3. Changes in $\beta$-glucuronidase activity of foetus and placenta during pregnancy. 0 , deficient rats; $\bullet$, normal rats (see p. I38).

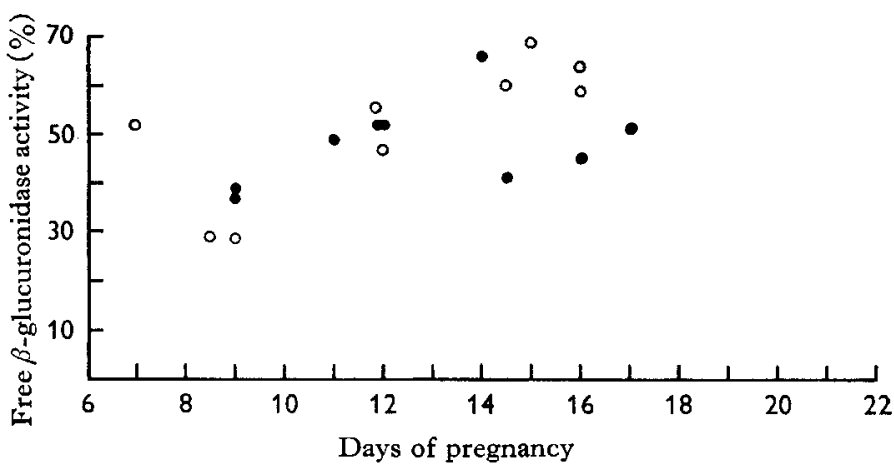

Fig. 4. Changes in free $\beta$-glucuronidase activity of foetus and placenta during pregnancy. 0 , deficient rats; $\bullet$, normal rats (see p. 138).

solely by the changes in foetal weight, shown in Fig. I. $\beta$-Glucuronidase activity found at II days may have been chiefly placental in origin because of the relatively small weight of the foetus. At r6-rg days, however, the increased weight of the normal foetus brought the contributions of the two tissues near to equality even though the placenta had $2 \frac{1}{2}$ times as much activity, on a protein basis. 


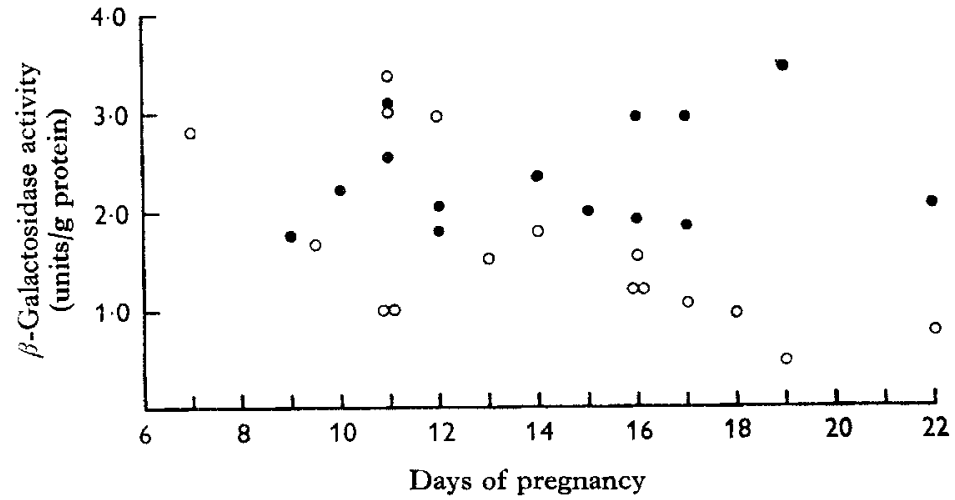

Fig. 5. Changes in $\beta$-galactosidase activity of foetus and placenta during pregnancy. 0 , deficient rats; $\bullet$, normal rats (see p. $13^{8}$ ).

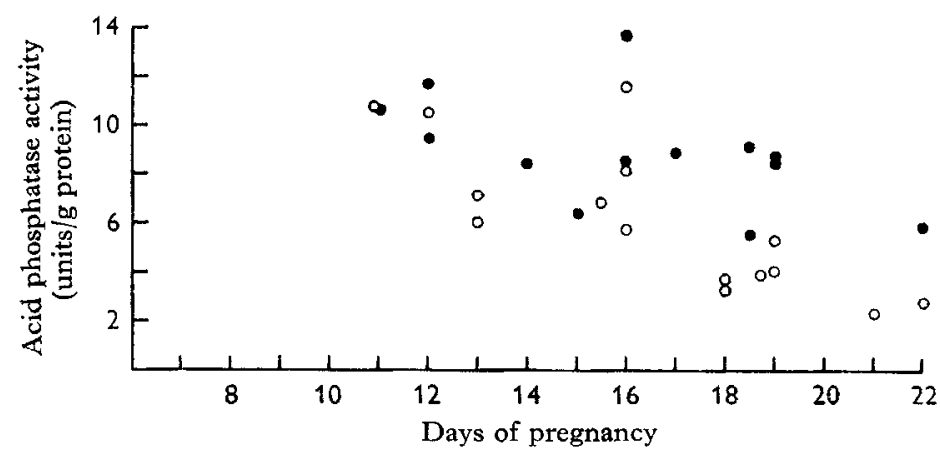

Fig. 6. Changes in acid phosphatase activity of foetus and placenta during pregnancy. 0 , deficient rats; $\bullet$, normal rats (see p. $13^{8}$ ).

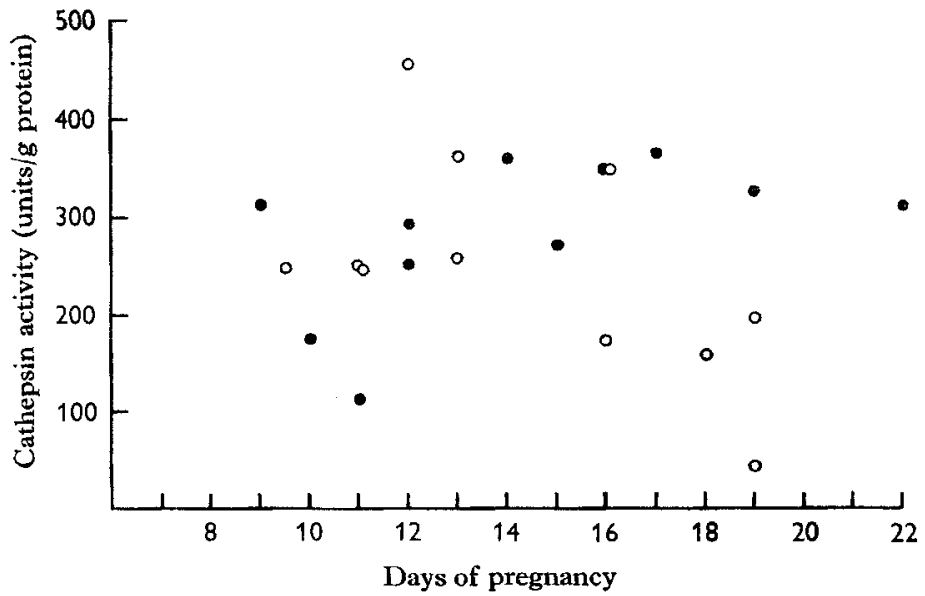

Fig. 7. Changes in cathepsin activity of foetus and placenta during pregnancy. 0 , deficient rats; $\bullet$, normal rats (see p. I38). 
A few tests were done to see if the proportion of free (unbound) activity was affected by pregnancy and vitamin E status. Fig. 4 shows that about $30-40 \%$ of the total activity was free at 9 days and that the proportion rose during pregnancy. Values for deficient rats were similar to those for normal rats, except on days 15 and $\mathrm{i} 6$, when a few higher results were recorded.

$\beta$-Galactosidase, acid phosphatase and cathepsin (Figs. 5-7). $\beta$-Galactosidase activities declined slowly in deficient rats during gestation and were mostly somewhat lower than normal values, which remained steady (Fig. 5). Acid phosphatase also decreased slowly during pregnancy, more so in deficient than normal rats (Fig. 6). All rats showed similar cathepsin activity during pregnancy except for a few low values in deficient rats on days 18 and 19 (Fig. 7). When expressed per implantation site, the activities of all these enzymes followed a pattern similar to that of the weight changes of the conceptus shown in Fig. $\mathrm{I}$.

\section{Table I. Effects of gestation and vitamin $E$ deficiency on hydrolytic enzymes in subcellular fractions of rat uterine contents}

\begin{tabular}{|c|c|c|c|c|c|}
\hline & & (On & per test) & & \\
\hline & & $\beta$-Glucuro & e activity* & $\beta$-Galacto & activity* \\
\hline Day & Fraction & $\begin{array}{l}\text { Normal } \\
\text { rats }\end{array}$ & $\begin{array}{l}\text { Deficient } \\
\text { rats }\end{array}$ & $\begin{array}{l}\text { Normal } \\
\text { rats }\end{array}$ & $\begin{array}{l}\text { Deficient } \\
\text { rats }\end{array}$ \\
\hline I I & $\begin{array}{l}\mathbf{L} \\
\mathbf{S}\end{array}$ & $\begin{array}{l}40,54 \\
60,46\end{array}$ & $\begin{array}{l}6 x, 60 \\
39,40\end{array}$ & $\begin{array}{l}30,49 \\
70,51\end{array}$ & $\begin{array}{l}71,48 \\
29,52\end{array}$ \\
\hline $14 / 16+$ & $\begin{array}{l}L \\
S\end{array}$ & $\begin{array}{l}84 \\
16\end{array}$ & $\begin{array}{l}67 \\
33\end{array}$ & $\begin{array}{r}100 \\
0\end{array}$ & $\begin{array}{l}72 \\
28\end{array}$ \\
\hline 17 & $\begin{array}{l}\mathrm{L} \\
\mathrm{S}\end{array}$ & $\begin{array}{l}62 \\
38\end{array}$ & $\begin{array}{l}29 \\
71\end{array}$ & $\begin{array}{l}72 \\
28\end{array}$ & $\begin{array}{l}35 \\
65\end{array}$ \\
\hline
\end{tabular}

$\mathrm{L}=$ lysosomal fraction; $\mathrm{S}=$ supernatant fraction. Activity determined by difference between the activity of the homogenate (crude homogenate after removal of debris) and the activity of the lysosomal fraction.

* As percentage of homogenate activity.

+16 days for the normal rats, but 14 days for the deficient rats.

Subcellular fractionation (Table $\mathrm{I}$ ). Compared to normal rats, deficient rats showed an equal or smaller proportion of $\beta$-glucuronidase and $\beta$-galactosidase activity in the supernatant fraction on day II; but there was more on days $14-17$, consistent with the greater free activity already described in deficient rats at this stage of pregnancy. However, in normal rats the supernatant fraction showed less proportional activity on days $I 6$ and 17 than on day $I I$, suggesting that the rise in free activity during pregnancy, already described, may be due to greater permeability of the lysosomes.

\section{Uterus and serum}

Uterus: weight and protein content. Uteruses from deficient rats declined in weight from about $\mathrm{I} \cdot 3 \mathrm{~g}$ on day II to about $0 \cdot 7 \mathrm{~g}$ on day 20 , whereas the weight of the normal uterus increased from $\mathrm{I} \cdot \mathrm{O}$ to $2 \cdot \mathrm{r} \mathrm{g}$. In both types of uterus, protein content increased from $5 \circ$ to $70 \mathrm{mg} / \mathrm{g}$ (day $\mathrm{II}$ ) to about $90 \mathrm{mg} / \mathrm{g}$ on day 19 and then decreased again to about $70 \mathrm{mg} / \mathrm{g}$. Normal uterus underwent greater changes than that in deficient rats. 
Uterus: $\beta$-glucuronidase and acid phosphatase. Uteruses from deficient and normal rats were tested between days II and 22. Normal uteruses showed a steady titre of $\beta$-glucuronidase activity (about 4 units/g protein), but acid phosphatase increased from II to I4 units/g protein. After 15 days, uteruses from some deficient rats had elevated values for $\beta$-glucuronidase ( $6-\mathrm{I} 2$ units/g protein) and acid phosphatase (24 units/g protein), but these were clearly not related to the death of the embryo, which occurred at about day I3. Other work (Arata, Santoro, Severi \& Pecora, I962) has shown the non-pregnant vitamin E-deficient uterus to have consistently lower $\beta$-glucuronidase activity than normal.

Serum: $\beta$-glucuronidase. There was no significant difference between the activities of normal and deficient rats, which both extended over the range $1 \cdot 3-2 \cdot 4 \mathrm{~m}$-units $/ \mathrm{ml}$.

\section{DISCUSSION}

During gestation-resorption in the vitamin E-deficient rat there were no changes in hydrolase activity comparable in magnitude to those found by us and by other workers in muscular dystrophy of the chick and rabbit. The only observed effect of vitamin $E$ deficiency, in embryo and placenta, was an increase in the size of the peak in $\beta$-glucuronidase values on days I I or I2, just before the death of the foetus on day I3 (Evans \& Burr, I927). These authors also found that the changes eventually leading to embryonic death were already evident as early as day 8 , the deficient embryo being retarded in development at all stages from the formation of the ectodermal cavity. Therefore, if there is greater $\beta$-glucuronidase activity in the deficient rat on day II it may be the result rather than the cause of the pathological changes. Cheng \& Thomas (I953) also found day 8 to be critical, for vitamin $E$ had to be given at or before this time if normal live young were to be born. When the dose was delayed until 9-12 days considerable numbers of malformed young were born. It would be interesting to study the effects of such late dosing on $\beta$-glucuronidase activity.

There is some doubt as to the metabolic function of $\beta$-glucuronidase. Mora, Cañedo \& Soberön (1965) studied the livers of starved rats and the tadpole tail during metamorphosis and concluded that $\beta$-glucuronidase functioned in the catabolic breakdown of mucopolysaccharides. They questioned the participation of this enzyme in the biosynthesis of ascorbic acid. However, Bulmer (1962), from his histochemical studies of the rat placenta, thought that $\beta$-glucuronidase was concerned less with the hydrolysis of glucuronides than with the conjugation of maternal oestrogenic hormones, thus restricting maternal influence on the genital development of the foetus. On this theory, the greater rise in $\beta$-glucuronidase activity in vitamin E-deficient rats might be a response to a higher output of maternal oestrogen.

The process of resorption of the dead embryos after day i3 does not seem to be associated with a change in the total activities of $\beta$-glucuronidase, $\beta$-galactosidase, acid phosphatase and cathepsin. Current theories of the origin and functions of lysosomal enzymes would suggest that the greater free $\beta$-glucuronidase activity in deficient rats in this period indicates breakdown of the lysosomal membrane and the liberation of enzymes that may be concerned in the hydrolysis of the dead tissue. However, 
there is little to suggest that these enzymes are implicated in the earlier stage before embryonic death.

During the second half of pregnancy, there develops on the outside of the rat uterus a glandular tissue, the glandula myometralis. Bloch (1964) has suggested that this tissue perforates the uterine wall at the end of pregnancy, liberating catabolic enzymes. In agreement with this, Woessner (1965) and Schaub (1964) found increases in several hydrolytic enzymes during post-partum involution of the uterus. Our finding of enhanced activity of $\beta$-glucuronidase and acid phosphatase in deficient uterus towards the end of pregnancy suggests that involution of the uterus takes place earlier in vitamin $\mathrm{E}$ deficiency.

We acknowledge the technical assistance of Miss R. J. Castle and Miss E. A. Murrell.

\section{REFERENCES}

Arata, L., Santoro, R., Severi, M. A. \& Pecora, P. (1962). Boll. Soc. ital. Biol. sper. $3^{8,} 215$.

Bloch, S. (1964). Acta anat. 56, 103.

Bulmer, D. (1962). Nature, Lond. 195, 805.

Bunyan, J., Green, J., Diplock, A. T. \& Robinson, D. (I967). Br. F. Nutr. 21, I27.

Cheng, D. W. \& Thomas, B. H. (1953). Proc. Iowa Acad. Sci. 60, 290.

Desai, I. D., Calvert, C. C. \& Scott, M. L. (1964). Archs Biochem. Biophys. 108, 60.

Desai, I. D., Calvert, C. C., Scott, M. L. \& Tappel, A. L. (1964). Proc. Soc. exp. Biol. Med. $115,462$.

Evans, H. M. \& Burr, G. O. (I927). Mem. Univ. Calif. 8, 1.

Evans, H. M. \& Bishop, K. S. (1922). Science, N.Y. 56, 650.

Mason, K. E. \& Harris, P. L. (1947). Biol. Symp. r2, 459.

Mora, J., Cañedo, L. \& Soberön, G. (1965). Biochim. biophys. Acta ıor, 137.

Schaub, M. C. (1964). Experientia 20,675.

Woessner, J. F. (1965). Biochem. F. 97, 855.

Zalkin, H., Tappel, A. L., Caldwell, K. A., Shibko, S., Desai, I. D. \& Holliday, T. A. (r962). F. biol. Chem. 237, 2678 . 